\title{
Utrökt eller avsköljd \\ Övergången från rök till vatten som rengörande substans bland svenska läkare under I800-talets slut
}

\author{
Annelie Drakman
}

Om vi på riktigt vill förstå hur sammankopplingen mellan renlighet och hälsa har förändrats bör vi försöka sätta våra egna uppfattningar om detta inom parentes. ${ }^{1}$ Undersökningen bör fokusera på hur frågorna: Vad är renlighet? och: Hur påverkar renlighet hälsan? har besvarats på främmande sätt under andra tider. Forskare bör vara särskilt uppmärksamma på skillnaderna mellan sina egna perspektiv och de historiska aktörernas. Vi bör avstå från att värdera praktiker på förhand, akta oss för att ta våra egna renlighetspraktiker för givna, och undvika antagandet att deras införande innebar att historiska aktörer äntligen kom till insikt. På så sätt kan vi förhoppningsvis undgå att förbise eller missförstå renlighetspraktiker som är annorlunda än våra egna.

I detta kapitel försöker jag följa dessa uppmaningar. Jag kommer att undersöka två skilda rengöringspraktiker symmetriskt, för att klargöra deras likheter och skillnader. För det första skildrar jag användningen och avskaffandet av utrökning av rum, en hälsofrämjande rengöringspraktik som övergavs under I800-talets slut. För det andra skildrar jag etablerandet av den hälsofrämjande rengöringspraktik som förmodligen är allra vanligast idag: rengöring via vatten, särskilt genom handtvätt. Min ambition är att presentera dem så värdeneutralt jag kan, utan att ta ett framgångstänkande - där rökning av rum är ineffektivt och bör överges - som utgångspunkt. 
Som källor använder jag till viss del artiklar publicerade av läkare i de svenska medicinska tidskrifterna Hygiea och Eira, men i huvudsak de cirka 5000 rapporter som skrevs av svenska provinsialläkare mellan åren I850 och 1900 och som har digitaliserats i Medicinhistoriska databasen, driven av Linköpings universitet. ${ }^{2}$ Provinsialläkare var statligt avlönade läkare som skickades ut i Sveriges alla provinser för att överse vaccinatörer och barnmorskor, inspektera apotek, förhindra och begränsa epidemier, bedriva egen läkarpraktik samt årligen inskicka en rapport till sin överordnade Sundhetskollegium i Stockholm. ${ }^{3}$ Systemet etablerades I688, kom under fullständig statlig kontroll år I773 och existerade fram till I973, då de sista provinsialläkarna blev lokalt avlönade distriktsläkare. Under I80o-talet mångdubblades antalet provinsialläkardistrikt då äldre distrikt avstyckades. År I820 fanns cirka 40 provinsialläkare i Sverige, år 1900 cirka 250 stycken. Provinsialläkarnas agerande styrdes genom en provinsialläkarinstruktion, som särskilt betonade deras rapportskyldighet. Utformningen av rapporten var helt fri fram till I850-talet, då ett system med rubriker klargjorde vilken information som efterfrågades. Rapporterna är mellan en och tio sidor långa och består generellt av beskrivningar av ort och befolkning, vanliga sjukdomar, klimatförutsättningar samt läkarens egna åtgärder. ${ }^{4}$

Provinsialläkarrapporterna är goda källor för att studera renlighet eftersom de återkommande beskriver smittoförebyggande, sjukdomshanterande praktiker, vilket ofta innefattar rengöring. Eftersom läkarna redogjorde för redan utförda handlingar för sina överordnade är det rimligt att anta att läkarna förstod dem som otvetydigt sanktionerade och ej uppseendeväckande: rapporterna ger därmed tillgång till normalpraktiker på ett sätt som mer uppfordrande och didaktiska texter, exempelvis artiklar, inte nödvändigtvis gör.

Mitt studieobjekt är hur det jag kallar för "sjukdomsframkallande smuts" identifierades och åtgärdades. Min forskningsfråga är: Vad ansåg svenska provinsialläkare vara verksamma metoder för att finna och rengöra smutsiga, sjukdomsframkallande omgivningar under åren I850I900? Äldre rengöringspraktiker ignoreras ofta i historiska översikter, vilket är beklagligt då de ger direkt insikt i uppfattningar om kroppar, smitta, sjukdom och renlighet. ${ }^{5}$ Förändringen i vilka rengöringsprak- 
tiker som användes och för vilka syften visar hur radikalt annorlunda dessa begrepp förstods på I80o-talet jämfört med under senare perioder.

För att undersöka hur renlighet har förändrats historiskt kommer jag som sagt att närstudera två rengörande praktiker. Under mitten av I8oo-talet rengjorde läkare sjukrum med hjälp av rökningar för att rena luften, en vana som övergavs på ı 870 -talet. Då började rengöring vid sjukdom istället att utföras med andra medel, särskilt tvättningar med vatten av kroppar.

För att förstå I 80o-talsläkarnas metodbyte kommer jag att undersöka vad som brändes för att skapa hälsobefrämjande rök, hur vatten förstods påverka kroppen, under vilka omständigheter metoderna användes samt vilka effekter de förväntades få. Därtill kommer jag att sätta rengöringsmetoderna i samband med I8oo-talets medicinska uppfattningar om hudens genomtränglighet, smittspridning och sjukdomsöverföring.

\section{Rengörande medelst rök}

Det är tydligt att renlighet i sjukrum inte företrädesvis uppnåddes med hjälp av vatten under mitten av ı8oo-talet. När kolerasjukhuset i Uppsala år I857 utrustades för 50 patienter rekvirerades I0,5 liter tjära för rökning men endast 425 gram tvål, vilket förväntades räcka under samma tidsperiod. ${ }^{6}$ Provinsialläkare beskrev också ofta hur de använde rök för att rengöra sjukrum. Läkaren i Hjo menade I854 att luften i sjukrum hölls "frisk" genom att "flere gånger om dagen rökas med enris eller Ättika, som slås på en varm skyffel". ' Läkaren i Eksjö skrev år I852 vid en epidemi att han genast förordnat att "rummen flere gånger om dagen skulle försigtigt rökas med enris". ${ }^{8}$ Även provinsialläkaren i Kalmar menade 1840 att det bästa sättet att motverka smittspridning i sjukrum var att rena luften med hjälp av rök:

Widare förbättras luften [...] med omwexlande af något af nedanstående: I:o/ På ett glödgadt jern lägges en portion groftmalna caffebönor, som kringbäres i rummet.

2:o/ Enris påtändes, hvarefter röken utsläppes genom dörr eller fönster. 3:o/ Ättika slås på ett glödgadt jern. Desse rökningar kunna göras 3 till 4 gånger om dagen.? 
Varför ansågs rök rena luften i sjukrum? Under första halvan av i80o-talet var det särskilt starkt luktande ämnen som brändes: kaffebönor, enris och ättika. Röken som uppstod ansågs skydda på två sätt: genom att dölja skadlig lukt och genom att förstöra smittämnen.

För det första ansågs rök vara nyttig för att den dolde lukten av förruttnelse. Läkarna försökte motverka ett ämne som var centralt inom västerländska smittspridningsteorier från antiken fram till ungefär I880-talet: miasma. ${ }^{10}$ Ruttnande organiskt material, som växtrester i träsk - men även ruttnande människokött vid sjukdomar som kallbrand - ansågs utsöndra en stank som kunde sprida förruttnelseprocessen vidare till allt den kom i kontakt med. Stanken kallades miasmatisk, och var en nedsmutsande, förorenande och sjukdomsframkallande substans: lukten av förruttnelse var både ett tecken på sjukdom inuti den sjuke och sjukdomsalstrande materia i sig. ${ }^{11}$ Genom miasmabegreppet förklarade läkare hur skämd lukt förgiftade luften och gjorde den hälsovådlig. En tyfusepidemi i Sundsvall år I 824 sades exempelvis ha spridits då varma rum fylldes med "ruttna uttömningars utdunstning". ${ }^{12}$ Vissa sjukdomar, däribland malaria, antogs alltid orsakas av miasmatiska ångor och dimmor från träsk, men miasmateorin användes för att förklara uppkomsten av epidemier av de flesta sjukdomar i de fall många personer insjuknat samtidigt och ingen smittspridningskedja från person till person var uppenbar. Att identifiera, motverka och åtgärda förgiftad luft var därför en vanlig sjukdomsförebyggande och sjukdomsbehandlande praktik i provinsialläkarrapporter fram till ungefär I88o-talet.

Hur kunde lukt anses orsaka sjukdom? Miasmateorin uppstod under antiken. Lukthistorikern Richard Palmer har undersökt vad som skrivits om det miasmatiska sjukdomsinflytandet och om luktsinnet i flera verk av den antika medicinens mest inflytelserike läkare, Galenos. Enligt denne var näsan inte luktsinnets organ utan bara en passage där lukt färdades till det luktande organet - hjärnan. Luktsinnet var enligt Galenos det enda sinne som inte behövde något organ för att förmedla intrycken. Lukt verkade omedelbart på själva hjärnan. ${ }^{13}$

Under medeltiden framställde flera filosofer lukter som materiella sinnesintryck. Juan Bravo skrev exempelvis I 583 att ljus- och färgintryck var immateriella - när ett objekt avlägsnades kunde det inte längre ses. 
Men avlägsna en ros och dess doft dröjer kvar: lukten kunde existera separat från objektet som givit upphov till den. ${ }^{14}$ Eftersom dofter ansågs vara fysiska substanser med direkt påverkan på hjärnan menades de vara särskilt benägna att både orsaka sjukdomar och bota dem, eftersom de förmedlade kvaliteter från de skadliga eller hälsosamma substanser ur vilka de uppstått. ${ }^{15}$

Fram till I80o-talets mitt antog läkare att människokroppen var öppen, sårbar och känslig för yttre påverkan. ${ }^{16}$ Dessa uppfattningar förstärktes från och med mitten av I700-talet i och med uppsvinget för det vetenskapliga intresset för pneumatisk kemi, där man studerade olika gaser, företrädesvis luft. Ett svenskt exempel på en pneumatisk kemist är för övrigt Carl Wilhelm Scheele (I742-I786), som upptäckte syret under I770-talet. Flera pneumatiska kemister gjorde direkta kopplingar till medicin eftersom luft antogs tränga in i levande organismers själva kärna, exempelvis Stephen Hale, som var en av grundarna av studiet av gaser under tidigt I700-tal. ${ }^{17}$ Luft penetrerade levande kroppar genom att forcera hudens porer, andas in och sväljas. Efter inträngandet fick luften kroppsvätskorna att svälla eller krympa, samt fibrers spänning att öka eller minska. Luft fungerade också som bärare och förmedlare av hälsovådliga ämnen, och lyftes därför fram som orsak till just epidemier. ${ }^{18}$

Teorin om sjukdomsframkallande stank och smitta förmedlad via luft ledde därmed till att stora rykande bål tändes i europeiska och amerikanska städer under epidemier från medeltiden och framåt, fram tills under koleraepidemierna på I850-talet. Rök, med sin skarpa, genomträngande doft, ansågs skydda eftersom den minskade förmågan att förnimma andra lukter. Flera andra sätt varigenom sjukrum rengjordes, exempelvis "beströ golfwet med friskt hackadt granris och bestänka det med ättika", ${ }^{19}$ handlade om att dölja lukt snarare än att avlägsna materia som uppfattades som smutsig. De dräkter läkare bar under epidemier var också utformade för att förhindra att bäraren kände hälsovådlig stank. På bilden av en pestläkare nedan används en rykande stav för att omge läkaren med ett moln av skyddande rök. Den distinkta näbben innehåller också välluktande örter för att förhindra att miasmastanken trängde in i läkarens näsa. 


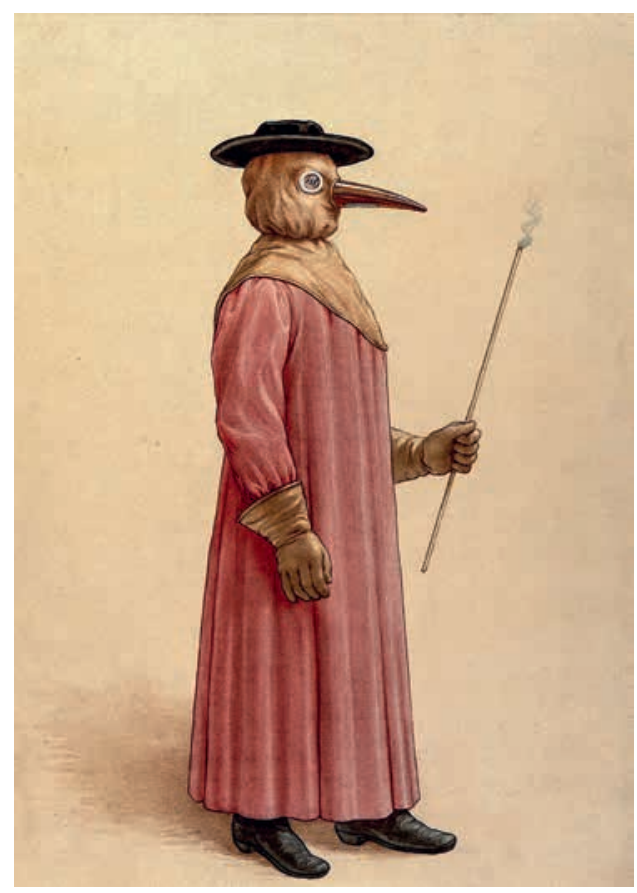

Bild 2.I. Illustration i akvarell av en läkare som bär pestdräkt från I6oo-talet, inklusive en näbb fylld med välluktande örter samt en rykande stav för att skydda sig mot pesten. Källa: Wellcome Image Collection/konstnär okänd.

Vädring var ett annat sätt att motverka stank, och därför betonade läkaren i Gävle I866 att det var viktigt att "anwända rökning med tjära" just "på ställen, der icke tillräcklig luftwexling kan åstadkommas, såsom i små, trånga, smutsiga gränder, gårdar och förstugor, fattigbaracker, m.m." ${ }^{20}$

Rök var också ett speciellt sätt att förändra objekt på: det kunde omvandla tings egenskaper på djupet, och verkade inte som andra medel enbart på deras yta. Exempelvis torkades och konserverades fläsk och annat kött med rök eftersom rökt kött inte ruttnade på samma sätt som färskt.

Röken antogs alltså tränga ut och dölja skadlig förruttnelsestank. I vissa fall kunde den även förstöra själva det skadliga ämnet. I en artikel i Tidskrift för läkare och pharmaceuter menade en läkare att skadliga 
luftburna utsöndringar oskadliggjordes snarare än doldes av rök. Han skrev att "ångan af kaffebönor, som rostas, eger förmågan att icke allenast göra animaliska och vegetabiliska effluvier okännbara för lukten, utan äfven att alldeles förstöra dem”. ${ }^{21}$

Även att röka tobak kunde uppfattas som hälsosamt under första halvan av I80o-talet. Tobak kunde ibland användas medicinskt av läkare under tidigt I800-tal vid lavemang, då tobaksrök retade ändtarmen. ${ }^{22}$ Att andas in tobaksrök var också en metod svensk allmoge kunde använda för att försöka bota sjukdom. ${ }^{23}$ Exempelvis skrev provinsialläkaren i Ström år I88I att de lokala kvinnorna rökte tobak "såsom botemedel mot magsmärtor". ${ }^{24}$

Tobaksrök kunde också förstås som ett skydd, ett sätt att föra med sig ett rökhölje in i omgivningar där individen annars riskerade att angripas av skadlig smitta. När målaren Carl Aspelin i början av I900-talet skapade målningen Läkarbesöket (förmodligen baserad på hans far, Gustaf Aspelin, provinsialläkare i Brösarp på I850-talet) skildrades läkaren med en tänd cigarr i sin vänstra hand. ${ }^{25}$

Fram till ı88o-talet beskrev provinsialläkare sällan rökning som ett medicinskt problem, förutom då allmogen rökte för att döva sin hunger. Vid de få tillfällen rökning ifrågasattes problematiserades bara att den rökande individen försökte skydda enbart sig själv. Rökning kunde framställas som en akt som var självisk snarare än skadlig för den rökande personen och dess omgivning. Provinsialläkaren i Naum år 1879 förebrådde exempelvis en frisk kvinna vars familj drabbats av epidemi för att hon rökte istället för att städa: "I stället för att företaga en grundlig rensning af huset, förekom en af husets döttrar rökande cigarr för att bevara sig för smitta." ${ }^{26}$

Från I86o-talet och framåt blev det ämne som brändes för att skapa röken allt viktigare. Tidigare hade olika starkt luktande ämnen, som enris och kaffebönor, kunnat ersätta varandra, men nu blev den kemiska sammansättningen av ämnet som röktes betydelsefull. Främst framhävde provinsialläkarna det nyttiga i att genomföra rökningar av svavel.

Svavel används för att framställa tändstickor, krut och fyrverkeripjäser och är frätande och irriterande för huden. ${ }^{27}$ Svavelrökningar användes medicinskt under hela I80o-talet, bland annat som behandling mot 


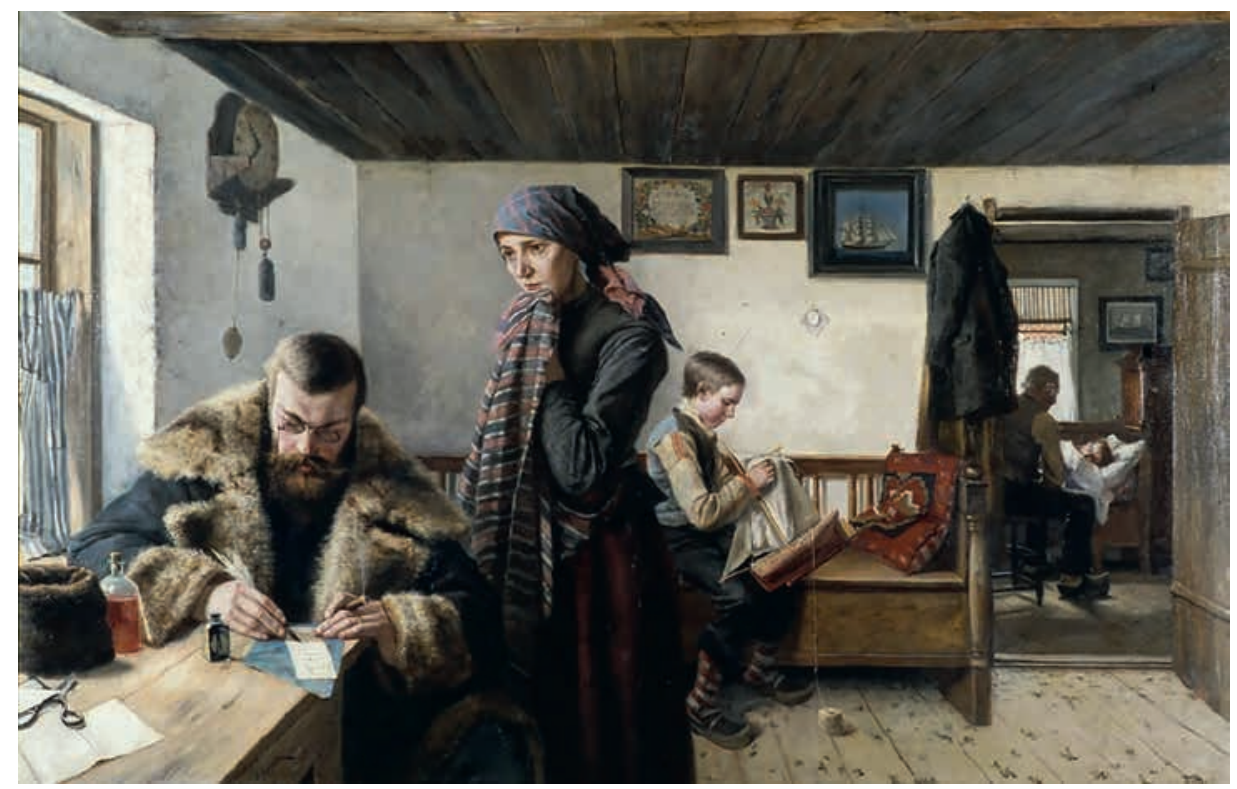

Bild 2.2. Läkarbesöket. Oljemålning föreställande en provinsialläkare (konstnären Carl Aspelins far) som skriver ut ett recept till en sjuk patient, tidigt I900-tal. Källa: Nationalmuseum/konstnär Carl Aspelin.

veneriska sjukdomar. ${ }^{28}$ Läkaren i Jönköping försökte år I844 exempelvis åstadkomma utslag på en patients rygg med hjälp av svavel för att avlägsna skadliga ämnen från kroppens djup. ${ }^{29}$ Svavel var ofta även det verksamma ämnet i kurbads och hälsobrunnars mineralhaltiga vatten. ${ }^{30}$ Enligt etnologen Ebbe Schön användes svavel även inom svensk folktro för att skydda mot trolldom genom att bäras i kläderna eller brännas inomhus för att förhindra sjukdomar och olyckor. Svavlet ansågs verksamt just på grund av sin påträngande och tydliga lukt. ${ }^{31}$

Från ungefär I870-talet och framåt omnämndes svavel i provinsialläkarrapporter nästan enbart för att beskriva hur läkare desinficerat sjukrum med hjälp av svavelrökningar. ${ }^{32}$ När människor vårdades för dysenteri på Akademiska sjukhuset i Uppsala år I883 beskrevs i sjukhusets årsrapport att man motverkat vidare smittspridning med hjälp av "svafvelrökningar", både av tomma salar och i salar där patienter befann sig. Detta gjordes för att "desinficera". ${ }^{33}$ Även allmogen sades 
lita på svavlets förmåga att förebygga smittspridning. Läkaren i Umeå skrev år I88I att "både Karbolsyran, tack vare dess 'friska' lukt och svafvelrökningen åtnjuta stort förtroende". ${ }^{34}$

Detta var en sedan länge etablerad praktik: i Svenska Akademiens ordbok nämns att svavelrök har en desinficerande verkan och man citerar Vetenskaps-handlingar för läkare och fältskärer från I798, där det upplyses om att: "De medel Chemien föreslaget till Smittors quäfvande äro: At afbränna Svafvel och kol. At afbränna Svafvel och Arsenik (osv.)."35 Den medicinska användningen av svavel var alltså väl etablerad under hela seklet även om ordet svavel/swavel/svafvel/swafvel blev vanligare i provinsialläkarrapporter mot I8oo-talets slut: ordet förekommer 48 gånger mellan I850 och I875 men mer än dubbelt så ofta, I25 gånger, mellan åren I875 och I899. ${ }^{36}$

Men även om svavelrökningar diskuterades allt oftare mot slutet av I80o-talet började läkarna beskriva alla andra slags terapeutiska och preventiva rökningar som ineffektiva. Redan I857 finns ett exempel på hur en provinsialläkare menade att rökningar förvärrade snarare än förbättrade luftens sammansättning. Läkaren i Lidköping skrev om ett sjukrum att "den instängda luften var förpestad af den odrägligaste lysentiva stank, som genom välmenta rökninger med enris blifvit ännu vidrigare" ${ }^{37}$ I detta fall sades rökningar alltså inte längre förstöra eller dölja det nedsmutsande och skadliga ämnet, utan istället bidra till nedsmutsningen.

Under 1900-talet började rökning alltmer uppfattas vara en hälsovådlig praktik, som människor ägnade sig åt för njutning och förströelse snarare än för att skydda sig mot sjukdom. ${ }^{38}$ Rök hade förlorat förmågan att desinficera och blev ett hälsohot i sig själv. Den började beskrivas som en giftig substans som skadade snarare än skyddade kroppen, och ansågs smutsa ner snarare än rengöra omgivningen. ${ }^{39}$

Processen där rök gick från renande till nedsmutsande påbörjades under slutet av I800-talet. Då började också rök kallas hälsovådligt i provinsialläkarrapporter. Visserligen menade en provinsialläkare redan I866 att den rök som användes för att röka ihjäl råttor även skadade människor, ${ }^{40}$ men i övrigt framställdes sällan rök som skadlig i provinsialläkarrapporter förrän kring I880-talet, då en läkare menade att 
"Nicotinismus chronicus" var en vanlig förgiftningssjukdom, ${ }^{41}$ och en annan menade att allmogen rökte "en svart giftig tobak" ${ }^{42}$ Läkaren i Tanum menade I897 att "tobaksrök, matångor och rök från eldstäderna" förorenade luften i allmogens hem och gjorde dem smutsiga och sjuka. ${ }^{43}$ Läkaren i Höganäs skrev I895 angående fabrikerna i hans distrikt att de orsakade "olägenheter" för den lokala hälsan, "såsom luftens förorenande af koldam och rök" ${ }^{44}$ Rök hade blivit smutsigt och farligt.

Från och med mitten av I880-talet blev det också vanligare att betona att rökningar av sjukrum var verkningslösa. Rökningar framställdes som bekväma och lättvindiga sätt att skydda sig mot smitta i motsats till verkligt effektiva metoder. Läkaren i Motala skrev år I885 att epidemier var vanliga $i$ hans distrikt delvis på grund av att desinfektion av sjukrum aldrig förekom, utan bara "möjligen rökning med enris". ${ }^{45}$ På samma sätt skrev läkaren i Tingsås år I 898 att allmogen i hans distrikt

vill nog hafva hjälp och skydd mot smittan, men man vill hafva den på något beqvämt och lättvindligt sätt som t.ex. genom att [...] röka med enris [men] att underkasta sig några förändringar i sitt dagliga lif [...], det kommer aldrig eller nästan aldrig i fråga ${ }^{46}$

Vad menade han med "förändringar i sitt dagliga lif"? Att sjukdom och smitta nu inte borde motverkas genom rökning efter att sjukdom inträffat, utan snarare borde förebyggas genom daglig rengöring av kroppar med vatten.

\section{Övergång till tvättande av kroppar med vatten}

Fortfarande under tidigt I880-tal kunde rengöring under och efter epidemier sägas göras enbart genom tvättning av kläder, rökning av rum och skurning av golv, utan att rengörandet av kroppar alls diskuterades. ${ }^{47} \mathrm{Men}$ en förändring var på gång: allt oftare började tvättning av kroppar med vatten beskrivas som en rengörande och sjukdomsförebyggande praktik.

När provinsialläkaren i Kristianstad I 882 utfärdade "råd och anwisningar rörande åtgärder mot rödsot” var just tvättandet av kroppar med tvål och vatten den centrala praktiken för att motverka smitta. Han menade att alla som vårdat sjuka "böra efter hwarje beröring 
twätta sina händer med karbolsyre-twål”, precis som "de som biträda wid swepningen af liket, böra, till undwikande af smitta, efteråt wäl twätta sig med karbolsyre-twål” ${ }^{48}$ När samma läkare ställde upp en lista med I7 punkter över praktiker för att motverka smitta nämndes inte rökning alls. ${ }^{49}$

Hur uppfattningar om vattnets terapeutiska och preventiva verkningssätt förändrades under I800-talets lopp har inte studerats tillräckligt utförligt. Med få undantag har historiker skildrat vattnets rengörande egenskaper som självklara snarare än som konstituerade i en historisk process. ${ }^{50}$ Därmed har människors ökande intresse för vattenrenlighet från mitten av I80o-talet och framåt genomgående framställts som ett tecken på att okunskap övergått i insikt. Exempelvis skriver historikern Virginia Smith i boken Clean, en historisk översikt över rengöringspraktiker, att "från och med I840-talet vände den populära sanitära reformrörelsen sin uppmärksamhet mot två medel för att motverka smutsighet som båda alltför länge ignorerats: tillgången till rent vatten och offentliga badanläggningar" ${ }^{51}$ Smith beskriver alltså att användandet av vatten "alltför länge ignorerats". Därmed döljer hon det mödosamma och alls inte självklara arbetet med att förändra uppfattningar om vatten till att vara en substans som verkade ovanpå huden snarare än trängde in i kroppen, och som sköljde bort smuts snarare än påverkade kroppens inre flöden. För ämnet vatten har inte alltid uppfattats som det görs idag. Den franske historikern Georges Vigarello har påpekat att "mycket mödosamt arbete över lång tid behövdes för att vatten skulle uppnå den genomskinlighet och oskyldighet det förstås ha inom nutida hygientänkande. Det finns andra sätt att uppfatta vatten på än vårt eget". ${ }^{2}$ Att vatten associerades med renlighet var konsekvensen av en övergripande och djupgående förändring i uppfattningarna om vad renlighet innebar, samt uppfattningar om hur vatten och kroppar interagerar.

Att läkarnas hygieniska ideal och praktiker förändrades radikalt under den sista tredjedelen av I80o-talet hänger naturligtvis samman med att vetenskaplig medicin slog igenom under dessa årtionden. ${ }^{53}$ Provinsialläkare år I850 besatt helt andra kunskaper och eftersträvade helt andra mål jämfört med sina efterföljare år I900. Det huvudsakliga medlet varigenom nya insikter och förändrade metoder förmedlades till 
läkare var de medicinska tidskrifterna. När Svenska provinsialläkarföreningen började ge ut sin egen tidskrift Eira I877 blev en stor andel provinsialläkare prenumeranter redan från början. Att flertalet även läste Hygiea, tidskrift för svensk läkekonst, den dominerande svenska medicinska tidskriften som grundats redan I822 av Svenska Läkaresällskapet, demonstreras av att uppmaningar till provinsialläkare återkommande publicerades i Hygiea istället för att cirkuleras brevledes. ${ }^{54}$ I dessa tidskrifter förekom förutom inhemskt författade artiklar många översatta referat ur de viktigaste franska, tyska och brittiska läkartidskrifterna. Receptionen av internationell medicin gick generellt snabbt och nya tekniker och terapier togs ofta i bruk bara efter något år - till exempel utfördes den första svenska vaccinationen i Lund I800, mindre än två år efter Edward Jenners artikel om denna nya metod i juni 1798.55 Denna snabba kunskapsöverföring var genomgående under I80o-talet: ett ytterligare exempel är att flera svenska provinsialläkare ivrigt diskuterade bakteriologiska praktiker under I880-talet. ${ }^{56}$

I både Hygiea och Eira diskuterades också nya renlighetspraktiker återkommande under I870-talet. För svenska I80o-talsläkare hade förmodligen den brittiske kirurgen Joseph Listers nya metoder störst praktiskt inflytande. På I870-talet revolutionerade Lister kirurgisk praktik och minskade dödligheten dramatiskt genom sin nya metod för att skapa antiseptiska zoner kring öppna sår med hjälp av bland annat karbolsyresprayer och flitig handtvätt. ${ }^{57}$ Svenska läkare publicerade många artiklar om Listers metoder. I Eiras första nummer från I877 redogjorde exempelvis provinsialläkare Söderbaum för "Listers antiseptiska behandling af abscesser", då han använt metoden under sju månader på sitt lasarett i Eskilstuna. Han kände inte till att någon annan svensk klinik använde metoden. Av avgörande betydelse, menade Söderbaum, var att allt som berörde abscessen rengjordes både med vatten och med en blandning av 97,5 procent vatten och 2,5 procent karbolsyra. Innan abscessen vidrördes var det viktigt att "operatören tvättar sina händer först i vanligt vatten, sedan i den svaga lösningen". ${ }^{58}$ Söderbaum skrev för övrigt sin akademiska avhandling om just Listers antiseptiska metod, och tillät dess huvudpoänger återtryckas som en följetong i Eira. ${ }^{59}$ Just handtvättandet lyfts av Söderbaum och flera andra fram som cen- 
tralt, även för läkare. Detta kan sättas i relation till hur handtvättande beskrivs i den mest inflytelserika brittiska medicinska tidskriften under I870-talet, British Medical Journal, där handtvättande såvitt jag kunnat finna enbart diskuteras i relation till underordnade medicinska utövare, som barnmorskor. ${ }^{60}$ I svenska medicinska tidskrifter tycks det alltså oproblematiskt att uppmana även läkare att tvätta händerna.

I Eira förekom under I870-talet också återkommande förmaningar om de hälsofaror som hotar vid huslig orenlighet. Exempelvis skrev en doktor Ribbing en lång artikel om linnetvätt där han beklagade att trots att "välförsedda linneskåp är en svensk husmoders stolthet" så tvättade man i många hem bara två gånger om året, vilket skadade "det husmoderliga ordningssinnets sträfvanden". ${ }^{61}$ Därtill blev man tvungen att spara smutstvätt som under tiden ofta användes av tjänare vilka kunde smitta ner kläderna med tyfus, kolera och så vidare. Därför menade Ribbing att kommuner borde uppföra fler tvätthus, till exempel täckta klappbryggor, så att tvätt kunde anordnas oftare. Att det blev dyrare att tvätta kläder oftare medgav han, men menade att detta är en nödvändig kostnad då tvätthanteringen var en "vigtig helsovårdsfråga". ${ }^{2}$ Huslig renlighet ansågs alltså vara en fråga av betydande medicinskt intresse - liknande artiklar är ytterst sällsynta före I870-talet.

Under I80o-talets sista tredjedel började alltså svenska läkare att på flera olika sätt uttala sig om hur renlighet medelst vatten kunde förebygga sjukdom och hälsa. Svenska provinsialläkarföreningen - som företrädesvis drev frågor om statliga läkares lön och yrkesförmåner - använde sig också av dessa nya hygieniska idéer och praktiker, samt landsbygdsbefolkningens motsträvighet mot dem, som ett argument för läkaryrkets viktiga samhällsfunktion. ${ }^{63}$

Allt detta ledde till ett dramatiskt uppsving för vatten som huvudsakligt medel för att uppnå renlighet och därmed hälsa bland läkare från I870-talet och framåt. Men för att vatten skulle bli ett självklart renlighetsbefrämjande medel behövde flera uppfattningar om interaktionen mellan kropp och vatten förändras på ett grundläggande sätt. Att vatten användes för att rengöra var alls ingen självklarhet, utan resultatet av en mödosam historisk process. 
För samtidigt som läkare började lyfta fram vatten som rengörande medel stegrades balneologins inflytande. Balneologin är en medicinsk gren, numera övergiven, som lär ut att badande är hälsosamt på grund av vattnets temperaturreglerande och inträngande egenskaper. Den var som mest inflytelserik under I80o-talet, men härrör från många hundra år av badande i mineralrika källor.

Många texter som förespråkar balneologiska behandlingsmetoder förekommer också exempelvis i Eira under denna tidsperiod. År I877 skrev flera läkare artiklar som förklarade hur bad kunde bota lungsot. I artikeln "Om bad mot lungsot" förklarade dr Dovertie att bad stärkte kroppen eftersom de orsakade en "förändrad respirationstyp", baden retade nerverna vilket ledde till ökad förbränning och förbättrad syresättning. Därför kallades baden "toniserande", det vill säga stärkande. ${ }^{64}$

Innan I860-talet använde även provinsialläkare vatten främst utifrån dess inträngande egenskaper. Att bada, låta vatten skölja över huden eller att badda med våta trasor antogs under första halvan av i80o-talet och tidigare främst påverka kroppens insida. Huden framställdes som en sluss snarare än som en fast yta, och badande innebar att låta vatten öppna upp och strömma in i porerna för att påverka kroppens hela konstitution. Det märks på två sätt: dels genom att bad antogs förändra kroppens inre vätskeflöden och organ, dels genom att läkare och allmoge fokuserade på vattnets temperaturreglerande egenskaper.

Fram till ungefär I860-talet antog provinsialläkare att bad verkade främst på kroppens insida. Bad som terapeutiskt ingrepp beskrevs exempelvis som "invärtes" medel när läkaren i Uppsala I823 räknade upp sina terapeutiska verktyg. ${ }^{65}$ När läkaren i Ljungby 1836 låtit utföra en kemisk analys på en lokal hälsobrunns vatten fann han att "vattnet innehåller flere ämnen, som gifva dess verkan en bestämd riktning, som göra den mera genomträngande och ingripande i sjelfva vegetations-processen" ${ }^{66}$ Han menade alltså att hälsobrunnens vatten var ovanligt potent då det kunde tränga särskilt djupt in i levande organismer för att påverka deras tillväxt- och förändringsprocesser. Kurbad användes för att bota åkommor långt in i människors kroppar, dit läkarens övriga ingripanden (mediciner undantagna) inte kunde nå, eftersom detta var före tiden då människor kunde genomgå bukoperationer och överleva. Badkurer 
sades bota gikt, avsaknad av menstruation, slaganfall, ${ }^{67}$ reumatism och "svag mage". ${ }^{68}$ I Luleå I 823 behandlades en lam flicka med bad, ${ }^{69} \mathrm{i}$ Strömstad I852 användes badvattnet för att motverka förstoppning, ${ }^{70} \mathrm{i}$ Hofors I 867 använde läkaren varma bad för att motverka njursjukdomar och lungemfysem. ${ }^{71}$ I Eksjö nådde läkaren stora framgångar med sina kurbadsbehandlingar vid Lannaskede hälsobrunn. Så här beskrev han vad som hände med patienter efter att de genomgått kurbad:

De voro besvärade af törst, uppstötningar, ömhet under bröstet, och förstoppning - bland consensuella symptomer anmärktes hjertklappning och smärta gående åt armarne - af mineralvattnet blefvo alla återställda. ${ }^{72}$

Poängen med kurbad var alltså att vattnet trängde in i människors kroppar och förändrade dem på djupet för att bota dem. Renlighet var inte viktigt. Patienter badade ofta i "smutsigt" vatten, det vill säga vatten som innehöll mineraler och därför kunde vara grumligt, brunt och lukta starkt av ruttna ägg om det innehöll svavel. Gyttjebad var också vanliga. Läkaren i Ljungby I836 menade att "uti granskapet finnes en göttja, som, i förening med förruttnade vegetabilier, innehåller betydligt jern och luktar starkt svafvelbundet väte, och tros derföre med fördel kunna användas vid bad". ${ }^{73}$ Att gyttjan ansågs vara särskilt nyttig inte bara trots utan just för att den innehöll ruttnande växtdelar visar hur oviktig renlighet var i samband med kurbadsbehandlingar.

Samma tendens att finna vattnets påverkan på renlighet oväsentlig märks i hur läkarna under tidigt I8oo-tal återkommande diskuterade vattnets temperaturförmedlande egenskaper som mest centralt. Att låta kroppar komma i kontakt med kallt vatten kunde ibland vara hälsosamt, som när läkaren i Vingåker rapporterade att menstruationsrubbningar och anemi avhjälptes enbart med behandlingar med kallt vatten, ${ }^{74}$ men kalla tvättningar kunde också orsaka sjukdom. Läkaren i Eksjö beskrev I840 exempelvis en kvinna som "genom kalla tvättningar hämmat blodflödet, hvarefter en långvarig sjukdom uppstod, som slutades med döfhet, hvilken fortfor hela lifvet igenom". ${ }^{75}$ Vattnets temperatur sattes alltså i direkt kausal relation till kvinnans förlorade hörsel. 
Från i860-talet och framåt började dock badande allt oftare sägas vara en rengörande praktik. Provinsialläkarnas beskrivningar av vatten som ett inträngande medium upphörde, och istället framställdes bad som en händelse där vatten sköljde över en kropps utsida snarare än påverkade dess inre. Det märks exempelvis genom att läkarna började diskutera huden som en plats vilken förtjänade medicinskt intresse i sig själv snarare än att uppfattas som enbart en sluss mot kroppens inre. År I897 skrev läkaren i Järvsö att det var tydligt att människorna i hans distrikt sällan badade eftersom de var så smutsiga. "Högst få hudytor", skrev läkaren, "befunna i detta afseende oklanderliga." "76 Läkaren beskrev alltså huden som en yta snarare än som en väg in i kroppen. På samma sätt föreskrev läkaren i Molkom I898 att patienter efter sjukdomar skulle "tvättas öfver hela kroppen först med formalinlösning [...] sedan med såpa och varmt vatten”, precis som föremål av metall, glas och porslin skulle "aftvättas med formalinlösning". ${ }^{77}$ Läkaren menade alltså att kroppen hade en utsida precis som porslinsföremål, och därmed kunde avtorkas och tvättas utan att vätskans inträngande i kroppen behövde diskuteras. Vattnet verkade utanpå kroppen snarare än på kroppens inre.

Provinsialläkarna slutade alltså $\mathrm{i}$ hög grad att framställa vatten som ett i kroppen inträngande medium, och beskrev det istället som något som trängde in enbart mellan kroppen och den vardagssmutsiga hinnan av kroppsutsöndringar på huden. Vatten blev ett medel för att skilja kroppen från de skadliga kroppsutsöndringar som huden ständigt genererade, och avsaknaden av bad började nu sägas resultera i smutsighet. Läkaren i Sigtuna I888 klagade över att eftersom "bad eller tvättning af kroppen" användes mycket sällan av arbetarklassen, fann han vid undersökningar återkommande "fötter och ben beklädda af mer eller mindre tjocka lager af smuts". ${ }^{78}$ Läkaren i Undersåker skrev I868 om lokalbefolkningen:

Sjelfva bostaden hålles i allmänhet snygg genom skurning, hvitmening och granrisning, men till kropparnes rengöring användes vanligen mindre vatten, än som vore önskvärdt. [För att rengöra kroppar] åtgå under årets lopp ej många kannor watten. [...] på de äldres kroppar får smutsen ofta samla sig från årtionde till årtionde. ${ }^{79}$ 
Läkaren i Söderåkra I878 beskrev också utförligt de rysliga effekterna av att vara ointresserad av vatten och tvål:

[D]en stora massan af den lägre befolkningen synes ej hafva något behof af att uppfylla ens de allra enklaste villkoren för kroppens vård genom vatten och såpa. Att bonden under sitt arbete uppträder med vildt vexande skägg, hoptofvadt hår, smutsigt ansigte och svärtade händer, må kanhända anses ursäktligt; men qvinnan i hemmet, som, naturligtvis med undantag af skägget, uppenbarar sig under samma skepnad, blir mera än obehaglig att skåda. Barnen, som ofta tulta omkring i blotta linnet, äro öfverhöljda af smuts. Stolar, bord och bänkar äro nerspillda, otvättade och betäckta med slumpvis kringkastade klädesplagg och trasor. Begäres en stol att sitta på, föser husmodern vanligen först undan ett par barnungar och stryker sedan ett drag med förklädet eller kjolen öfver stolsitsen, för att som hastigast få bort den lösa smutsen. Golfvet är så öfverdraget med spillda och fasttrampade ämnen, att foten understundom klibbar fast, när man går derpå. ${ }^{80}$

Vatten framställdes här som ett medel för att avlägsna smuts, vilket är en stor skillnad från att bad påverkade inre organ, sinnestillstånd och flöden av kroppsutsöndringar ut ur kroppen som under åren före I860-talet. Under sent I800-tal började läkarna föreskriva tvättningar med vatten som preventiva och terapeutiska rengörande praktiker. ${ }^{81}$ Användandet av vatten hade för läkarna under sent I80o-tal blivit en hälsofrämjande praktik genom sin koppling till renlighet, snarare än att badet hade terapeutisk inverkan på kroppen själv. Kroppen hade börjat uppfattas vara så pass sluten att strömmar av vatten inte längre antogs tränga in i den och förändra den i grunden. ${ }^{82}$

Tvättande blev därför långt mycket viktigare under sent I800-tal än tidigare. Detta skedde i samband med att kroppsutsöndringar i allt högre utsträckning började anses vara den materia varigenom sjukdom förmedlades. Att avlägsna kroppsutsöndringar från huden medelst tvättning innebar för sena I80o-talsläkare att avlägsna själva grogrunden för sjukdom. ${ }^{83}$

Därför började vatten under I80o-talets tredje del att diskuteras utifrån dess sköljande egenskaper, och tvättningar och bad beskrevs som 
hälsofrämjande praktiker eftersom de avlägsnade smuts från människors hud och hår.

Vattnets förmåga att avlägsna smuts hängde dock samman med om det användes tillsammans med tvål eller såpa. Under tidigt I8oo-tal tillverkades tvål ofta lokalt, genom att vegetabiliskt eller animaliskt fett kokades tillsammans med asklut, men mot seklets slut började tvål bli alltmer tillgängligt kommersiellt. Den industriella tillverkningen ökade och priset sjönk. ${ }^{84}$ I Storbritannien ökade tvåltillverkningen stadigt från I830-talet och framåt, och mängden tillverkad tvål ökade särskilt brant efter I852, då en tvålskatt avskaffades, ${ }^{85}$ men i Sverige tycks det ökande intresset för tvål ha skett något senare. Visserligen grundades den första svenska tvålfabriken, Göta Lejon i Örgryte i Göteborg, av köpmannen John Benecke redan I8I2. År I823 tillkom en fabrik i Stockholm, och i Sverige grundades ytterligare fyra före I850. ${ }^{86}$ Men det stora uppsvinget kom under I800-talets andra hälft: I9 tvålfabriker tillkom i riket mellan I85I och $1900 .^{87}$

I provinsialläkarrapporterna tog intresset fart från I880-talet och framåt. I de 8807 digitaliserade provinsialläkarrapporterna i Medicinhistorisk databas nämns ordet "tvål/twål” sammanlagt sju gånger mellan åren 1820 och I879, åtta gånger på I880-talet och fjorton gånger på I890-talet. ${ }^{88}$ Ordet "såpa" nämns nio gånger mellan I820 och I879, fyra gånger på I880-talet och tjugonio gånger på I890-talet. ${ }^{89}$ Innan I88o omtalades inte heller såpa nödvändigtvis i samband med rengöring av kroppar och ting. Såpa kunde under denna period i vissa sammanhang användas som medicin, som när en provinsialläkare provade att använda såpa som motgift mot arsenik, ${ }^{90}$ eller när en kvacksalvare använde såpa som ingrediens i en medicin som skulle till hälften drickas, till hälften smörjas på huden. ${ }^{11}$ Första gången såpa omtalas som något vilket används för rengöring är I86I, då grön såpa och varmt vatten används av en läkare för att tvätta huden för att få bort hudutslag. ${ }^{92}$ På samma sätt använde provinsialläkaren i Skellefteå I 867 såpa: vaccinationen försvårades av att allmogen hade så mycket skabb, vilket läkaren försökte motverka genom "bad 2 gånger i veckan". ${ }^{3}$ Såpan och vattnet användes här för hudåkommor, och ansågs alltså verka utanpå kroppen snarare än tränga in i den. 
Läkarnas omtolkning av vattnets påverkan på kroppen ledde till konflikter med allmogen. Att lokalbefolkningen vägrade bada var ett vanligt klagomål i provinsialläkarrapporter under seklets sista tredjedel. Skilda åsikter kring huruvida vatten verkade på kroppens inre eller yttre organ är, menar jag, en central orsak till detta: allmogen uppfattade fortfarande vatten som en inträngande substans.

Läkarna slutade uppmärksamma vattnets temperaturreglerande effekter från I860-talet och framåt, men för deras patienter var sådan inverkan relevant för hälsan under hela I80o-talets gång. Läkaren i Slite I890 förklarade exempelvis att "allmogen i allmänhet är mycket rädd för vatten" och att den genomsnittlige bonden därför luktade som om han "icke haft vatten på sig, sedan han döptes". ${ }^{4}$ Läkarna hade svårt att övertyga sina patienter om nyttan av användandet av vatten. Exempelvis sade flera läkare att sjuka brukade få ligga i smutsiga kläder. En läkare beskrev den vanligaste sjukbeklädnaden som

ofta ett linne, som väl från början varit hvitt, men på hvilket färgen numera icke kan urskiljas till följe af smuts. Husmodern urskuldar sig då ofta med att hon icke vågat eller vågar ömsa linne på den säng liggande, derföre att han är sjuk. ${ }^{95}$

Varför vågade husmodern inte byta linne på den sjuke? För att tvättande kylde ner.

Det var just frågan om huruvida den nedkylning tvättandet medförde var skadlig eller ej som orsakade konflikter. Läkaren i Lidköping skrev I885 exempelvis att i hans distrikt "torde en tvättning eller rengöring af hela kroppen höra till stora sällsyntheter", eftersom:

Förkylningsfruktan är måhända den mest spridda och djupast inrotade af alla våra endemiska sjukdomar. Denna sjukdom har utan tvifvel kostat många menniskor, stora och små, både helsa och lif. Man riskerar gerna bådadera, - om än ofrivilligt eller omedvetet -, genom en kronisk förgiftning eller en akut septisk eller infektorisk sådan, blott man tror sig kunna undvika en snufva. ${ }^{96}$

Läkaren menade alltså att patienterna, när de undvek nedkylning, istället riskerade att förgiftas av egna kroppsutsöndringar. För att vat- 
tenbaserade renlighetspraktiker skulle börja ses som nyttiga behövde läkarna etablera för det första att orenlighet skadade hälsan och för det andra att vatten inte gjorde det. För att tvättningar skulle uppfattas som hälsofrämjande behövde det både förstås vara ofarligt att klä av sig kläderna och att tvätta bort den hinna av smuts som allmogen ibland uppfattade som ett skyddande lager.

Flera som skrivit om svensk allmoges renlighetsnivå under I80o-talet nämner "fällen", det smutslager som av allmogen ansågs skyddande och värmehållande. ${ }^{77}$ Karin Johannisson påpekar att det inte är ologiskt att smutsen betraktades som ett försvar vilket precis som huden stängde främmande partiklar ute. ${ }^{98}$ Smutsen var nyttig. Tvättade man sig inte så ofta frös man heller inte lika lätt. Provinsialläkaren i Vrigstad skrev I850:

Oaktat pålysningar om renlighet, infinna sig Bewäringsynglingar till den grad smutsiga, likasom de voro uppdragne ur dy, att jag ibland med ett lätt instrument måste skrapa, synnerligast nedre extremiteterne, för att kunna urskilja, om lemmarne äro friska. På fråga, hvarföre de ej tvätta sig, blifo svaret: "för att kunna bibehålla värmen". ${ }^{99}$

Fällen fungerade som ett extra skydd mellan kroppen och en farlig omvärld.

Under början av I800-talet framställde även provinsialläkare kläder som barriärer mot kall eller fuktig luft samt skadlig, sjukdomsframkallande, giftig luft: nakenhet framställdes återkommande som riskfyllt. Men under sent I800-tal hade kroppens gränser börjat uppfattas som så fasta att läkarna antog det vara säkert och nyttigt att klä av sig naken, det vill säga att avlägsna kläderna, en av de barriärer som under tidigt I80o-tal varit en så viktig del i preventiv medicin.

Eftersom läkarna börjat uppfatta det som hälsosamt att låta vatten skölja över nakna kroppar blev de kring sekelskiftet 1900 alltmer inblandade i utbyggandet av badhus. Flera läkare diskuterade sådana badinrättningar som hälsosamma på ett sätt som hade varit omöjligt under tidigt I 800-tal. Till exempel beskrev provinsialläkaren i Sandviken I897 den lokala fabriksinrättningens nyinrättade badhus, med uppgift "att genom renlighet befordra helsa och trefnad", på följande sätt: 
Från afklädningshytten i bassinrummet går [den badande] I tr. upp till varmluftsrummet med fuktig värme. Der tappar han ljumt vatten i sin balja från en af de många kranarne i ena långväggen, och gör sig ren med tvål och borste, som hållas honom till handa. Från en stor cementvask midt i rummet med permanent tillförsel af kallt vatten förser han sig med afsköljningsvatten. Ligger en stund på lafven der och sedan i rummet bredvid med torr värme. Då han kommit i svettning går han derifrån ned i bassinrummet, der han får sin tempererade dusch. Badet afslutas med några simtag $\mathrm{i}$ [den $\mathrm{I} 8{ }^{\circ} \mathrm{C}$ varma] bassinen. Under de 2 dagar i veckan badstubadet serverats hafva 400 personer om dagen begagnat det. 70 à 80 personer hafva badat samtidigt utan att någon trängsel försports. ${ }^{100}$

För en provinsialläkare under tidigt I80o-tal hade sådana rengörande praktiker varit direkt skadliga snarare än hälsosamma. Att klä av sig hade inneburit att blotta en ömtålig, bräcklig kropp för skadliga inflytanden, särskilt som det skedde i samvaro med upp till 80 potentiellt smittspridande främlingar. Som jämförelse kan tas en beskrivning av Mariestads badhus år ı8ı6, då läkaren var mest utförlig angående de dörrar som skilde rummen åt där olika personer badade. Dörrarna var av central betydelse, menade han, för att de badande skulle "undgå vatten ånger eller dunster" från andra personers bad, vilka annars "besvärar andedrägten till den grad at han utgår i luften i den starkaste svettning, och med det samma risquerar förkylning" ${ }^{101}$ Det var år I8I6 helt centralt för badets nyttighet att badet skedde i enskildhet. Uppfattningarna om hur öppen människokroppen var mot utifrån kommande påverkan förändrades alltså dramatiskt från tidigt till sent I80o-tal.

\section{Slutsatser}

För att vattenrenlighet skulle kunna bli en utbredd, hälsofrämjande, ofarlig praktik behövde kroppens gränser mot omvärlden från och med mitten av I80o-talet förstås vara betydligt fastare än tidigare. Att vattenrenlighet blev centralt för den hygieniska rörelsen kring sekelskiftet I900 visar att läkare och sundhetsreformatörer hanterade en ny, mer sluten kropp i vilken vare sig vatten eller luft riskerade att tränga in genom huden. Den 
nya kropp som rengjordes i allmänna badhus var motståndskraftig mot omgivande luft oavsett dess temperatur och luftfuktighet. Det var denna förändring - att den slutna kroppen tagit över som läkarnas medicinska objekt - som möjliggjorde vattenrenlighet som central praktik för de hygienistiska rörelserna från I8oo-talets slut och framåt.

Vad kan vi lära oss av att läkare under mitten av I800-talet rengjorde sjukrum medelst rök, för att under slutet av seklet istället lyfta fram vatten och tvål som det huvudsakliga medlet för att uppnå renlighet? Rökningens minskade betydelse hänger rimligtvis samman med försvinnandet av miasma som sjukdomsförklaring, vilket i sin tur hänger samman med att läkare under I80o-talet börjar uppfatta människors kroppar som mer slutna och avgränsade från omgivningen än tidigare.

Därtill kan vi anta att smuts och smitta under I800-talets sista tredjedel i allt högre utsträckning började uppfattas vara en materia som klibbade fast vid kroppar och ting (och vilken därmed kunde motverkas med hjälp av tvål och vatten) snarare än en luftburen substans (vilken kunde motverkas via vädring och rök). Läkare blev mer uppmärksamma på kroppsutsöndringar och mindre uppmärksamma på förruttnelseångor från miasmatiska träsk. Renlighet föreskrevs därtill som en påbjuden vana, eftersom vattenrenlighet borde upprepas dagligen eller varje vecka, medan rökningar främst utfördes efter att sjukdom eller förruttnelse identifierats. Vattenrenlighet förebyggde snarare än åtgärdade ett medicinskt problem.

Som den finländske filosofen Olli Lagerspetz påpekat hör våra begrepp om smuts och renhet ihop med hur vi lever i världen: när ett fönster är smutsigt beror på hur ett bra fönster definieras, och hur ett bra fönster definieras beror på hur människor lever med det, hur det används. Att identifiera någonting som smutsigt är att ta på sig (eller avkräva någon annan) ett slags förvaltarskap för objektet, att notera en brist som behöver åtgärdas. ${ }^{102}$ Huruvida smuts påverkar människors hälsa beror på vad smutsen förstås göra med kroppen, samt hur påverkbar själva kroppen är, hur öppen den är mot utifrån kommande inflytanden. Allt detta - hur en kropp, dess omgivning, sjukdom och risk förstås - beror på kulturella faktorer som förändras över tid. Att undersöka hur människor under en viss tidsperiod förstod renlighet och hur de hanterade smuts ger oss en direkt inblick i hur de förstod komplicerade och abstrakta frågor kring 


\section{ansvarstagande, kroppslighet och trivsel. Vad som uppfattas som rent respektive smutsigt hjälper oss att förstå hur världen under andra tider har delats upp, hanterats och förståtts.}

\section{Noter}

I Delar av denna text utvecklar tankegångar först uttryckta i Drakman, Annelie, När kroppen slöt sig och blev fast: Varför åderlåtning, miasmateorin och klimatmedicin övergavs under I80o-talets mitt, Uppsala: Acta Universitatis Upsaliensis, 2018.

2 Databasen finns fritt tillgänglig på internet på webbadressen http://www.ep.liu.se/ databas/medhist.sv.asp (hämtad 2 februari 2021).

3 År I877 blev Sundhetskollegium till Medicinalstyrelsen; båda är föregångare till dagens Socialstyrelsen.

4 Drakman, 39-49.

5 Exempelvis diskuterar inte Virginia Smith rökning i sin översikt över historiska rengöringspraktiker. Smith, Virginia, Clean: A history of personal hygiene and purity, Oxford: Oxford University Press, 2008, 278.

6 I857 Uppsala Schultz. Måtten som användes var fyra kannor respektive ett skålpund. Denna samt följande referenser till provinsialläkarrapporter kan lokaliseras i Medicinhistorisk databas via sökningar på år, ort och efternamn.

7 I854 Hjo Tengstrand.

8 I852 Eksjö Bråkenhielm. Se även exempelvis I836 Wimmerby Hanström.

9 I840 Kalmar Ekman.

Io Barnes, David, The great stink of Paris and the nineteenth-century struggle against filth and germs, Baltimore: The Johns Hopkins University Press, 2006. Andra studier om miasmateorin under I80o-talet inkluderar Brown, Michael, "From foetid air to filth: The cultural transformation of British epidemiological thought, ca. $1780-1848$ ", Bulletin of the History of Medicine, vol. 82, nr 3, 2008, 515-544. Det viktigaste verket är dock fortfarande Corbin, Alain, The foul and the fragrant: Odor and the French social imagination, Cambridge: Cambridge University Press, 1986. Se även Pelling, Margaret, Cholera, fever and English medicine, 1825-1865, Oxford: Oxford University Press, 1978; Kiechle, Melanie, Smell detectives: An olfactory history of nineteenth-century urban America, Washington: Weyerhauser Environmental Books, 2017.

I I William Cullen, I70o-talsläkaren vars sjukdomsteorier många provinsialläkare undervisats inom, kallade sjukdomar relaterade till förruttnelse, exempelvis difteri, barnsängsfeber, scharlakansfeber och kallbrand, för septiska, och menade att de var astheniska sjukdomar som borde behandlas med stärkande medel istället för åderlåtning. Porter, Roy, The greatest benefit to mankind: A medical history of humanity, New York: W.W. Norton \& Company, 1997, 261.

I2 I824 Sundsvall Platzman. Detta är både förruttnelsesmuts, smuts som skadar genom förruttnelse, och smittosmuts, smuts som skadar genom att ha utsöndrats av en sjuk person, samtidigt.

I3 Palmer, Richard, "In bad odour: Smell and its significance in medicine from Antiquity to the seventeenth century", Medicine and the five senses, Bynum, W. F. \& Porter, Roy (red.), Cambridge: Cambridge University Press, I999, 6r. 
I4 Ibid., 62.

I5 Ibid., 65. Se även Temkin, Owsei, The double face of Janus and other essays in the history ofnedicine, Baltimore: Johns Hopkins University Press, 2006, 462: "Nuförtiden skiljer vi mellan att desinficera och att dölja lukt. Men så länge luftens förorening var det orienterande konceptet, vilket hängde på att nedsmutsning var märkbar för sinnena eller på grund av dess upplevda följder, var en sådan tudelning närmast omöjlig att göra." (Min översättning.)

I6 Drakman.

I7 Corbin, II.

I8 Ibid., I3.

I9 1866 Gävle von Sydow.

20 I866 Gävle von Sydow.

2I "Läkarenotis", Tidskrift för läkare och pharmaceuter, vol. 58, nr I, juli I832, 32-34.

22 Bamji, Alexandra, "Blowing smoke up your arse: Drowning, resuscitation, and public health in eighteenth-century Venice", Bulletin of the History of Medicine vol. 94, nr I, 2020, 29-63.

23 Se exempelvis 1845 Motala Ekström.

24 I88I Ström Smitt. Se även i856 Arvika Gullstrand; I858 Uddeholm Olander.

25 För Aspelin den äldres yrkesutövning, se exempelvis 1859 Brösarp Aspelin.

26 I879 Naum Grenander.

27 SAOB, uppslagsord "svavel", http://www.saob.se/artikel/?seek=svavel (hämtad den 2 februari 202I).

28 I820 Uppsala Schultz.

29 I844 Jönköping Sköldberg.

30 Se exempelvis I85I Uppsala Schultz.

3I Schön, Ebbe, Folktrons ABC, Stockholm: Carlsson Bokförlag, 2004, 260.

32 I879 Hofva Eckerbom; I883 Lima Ekelund.

33 Henschen, S. E., Årsberättelser från länslasarett m.m. I879-19I4, Uppsala: Akademiska, I883. Se även I88I Tierp Egerström; I88I Umeå Bergenholtz; I882 Linköping Nordenström.

34 I88I Umeå Bergenholtz.

35 SAOB, uppslagsord "svavel", http://www.saob.se/artikel/?seek=svavel (hämtad den 2 februari 202I).

36 I de digitaliserade provinsialläkarrapporterna i Medicinhistoriska databasen förekommer ordet "svavel/swavel/svafvel/swafvel" följande antal gånger: I820-tal 4, I830-tal 3, I840-tal 8, I850-tal 20, I860-tal 5, I870-tal 8, I880-tal 56, I890-tal 69.

37 I857 Lidköping Graewe.

38 Gately, Iain, Tobacco: The story of how tobacco seduced the world, New York: Grove Press, 2001.

39 Torell, Ulrika, Den rökande människan: Bilden av tobaksbruk i Sverige mellan I950tal och I990-tal, Linköping: Carlssons bokförlag, 2002. Men år I930 kunde 20679 amerikanska läkare fortfarande övertygas om att offentligt bekräfta att just Lucky Strike-cigaretter var "hälsosamma". Gately, 245.

40 I866 Gävle von Sydow.

4I 1883 Delsbo Bergman.

42 I887 Vänersborg Friman.

43 I897 Tanum Willén. 
441895 Höganäs Nyman.

45 I885 Motala Västra Bohnsack.

46 I898 Tingsås Brorström.

47 I878 Falun Küsel.

48 I882 Kristianstad Cimmerdahl.

49 Ibid.

50 De främsta undantagen från denna trend är Vigarello, Georges, The concepts of cleanliness: Changing attitudes in France since the middle ages, Cambridge: Cambridge University Press, 1988; Corbin.

5I Smith, 278.

52 Vigarello, 27.

53 Bynum, W. H., Science and the practice of medicine in the nineteenth century, Cambridge: Cambridge University Press, I990.

54 Se till exempel Cederskjöld, P. G., "Till Herrar Provincial-Läkare", Hygiea, vol. 7 , nr I2, I845, 379, där Carl Cederskjöld, professor i obstretrik i Stockholm, vänder sig till "herrar provinsialläkare" för att instruera hur de bör granska uppgifter lämnade från barnmorskor.

55 Broberg, Gunnar, "Liten svensk medicinhistoria”, Til at stwdera läkedom: Tio studier i svensk medicinhistoria, Gunnar Broberg (red.), Lund: Sekel, 2009, 3 I.

56 Se exempelvis I886 Eskilstuna Pallin; I888 Ronneby Neyber; I899 Borås Geete. Se även Eira och Hygiea från I 880-talet, där flera provinsialläkare diskuterade bakteriologiska praktiker.

57 Truax, Rhoda, Joseph Lister: Father of modern surgery, London: George G. Harrap, 1947.

58 Söderbaum, P., "Listers antiseptiska behandling af abscesser af Dr. P. Söderbaum i Eskilstuna”, Eira: Tidskrift för Helso- och Sjukvård, vol. I, I877, 52. Se även t.ex. Wiborgh, Aug., "Om antiseptisk sårbehandling vid mindre sjukvårdsanstalter", Eira: Tidskrift för Helso- och Sjukvård, vol. I, nr 7, I877, 20I-2 II.

59 T.ex. i Eira: Tidskrift för Helso- och Sjukvård, vol. I, nr I9, I877, 591-600.

6o Sökningar i British Medical Journals online-arkiv för I870-talet ger enbart träffar för sökord som "hand-washing", "washing hands" och "clean hands" i relation till barnmorskors händer, inte läkares. Se t.ex. "Remarks on antiseptic midwifery", British Medical Journal, vol. I, I879, 264.

6I Ribbing, Seved, "Om linnetvätt. Också en helsovårdsfråga. Af Dr. Seved Ribbing", Eira: Tidskrift för Helso- och Sjukvård, vol. I, nr 3, I877, 55.

62 Ibid., 59.

63 "Prlf Handlingar I880-1932"; "Provinsialläkarföreningens handlingar I882", Svenska provinsialläkarföreningens arkiv, förvaltat av Svenska Läkarförbundet i Stockholm. Se även Dahlborg, Carl, Svenska provinsialläkarföreningens historia I88I-1905, Stockholm, 1905 .

64 Dovertie, L. G., "Om bad mot lungsot", Eira: Tidskrift för Helso- och Sjukvård, vol. I, nr 3, I877, 73-79; Möller, Fingal, "Några ord om Vattenbehandlingen i enskild praktik", Eira: Tidskrift för Helso- och Sjukvård, vol. I, nr I9, I877, 586.

65 I823 Uppsala Schultz.

66 I836 Ljungby Billengren.

67 I848 Rättvik Wettergren.

68 I857 Vänersborg Kjellberg. 
69 I823 Luleå Waldenström.

$70 \quad$ I852 Strömstads Hälsobrunn Winberg.

7I 1867 Hofors Hesselgren.

72 I852 Eksjö Miltopée.

73 I836 Ljungby Billengren.

74 I850 Vingåker Aurell.

75 I840 Eksjö Ljungberg.

76 I897 Järvsö Hamne.

77 I898 Molkom Lindblom.

78 I888 Sigtuna Drake.

79 I868 Undersåker Bergwall.

80 I878 Söderåkra Dahlberg.

8I I898 Hova Kolm.

82 Se Drakman, I20-157, I89-195.

83 Det kan tyckas som att alla kroppsutsöndringar blev till smuts i och med den vattenbaserade renligheten, men jag vill testa tanken att det snarare var kroppsutsöndringar som enkelt kan sköljas bort som definierades som smuts. Läkarna lyfte inte upp avföring som smutsig inuti tarmen, och karies eller tandsten ansågs ej vara smuts.

84 Heimbürger, Hjalmar, ”Den svenska tvättmedelsindustrien, med särskild hänsyn till förhållandena före världskriget", Statens offentliga utredningar: Tull- och traktatkommitténs utredningar och betänkanden XXXI, Stockholm, I925, 8.

85 Smith, 29of.

86 Heimbürger, 8.

87 Ibid.

88 Antal träffar för sökordet "tvål/twål" i Medicinhistorisk databas, https://ep.liu.se/ databases/medhist/: I820-tal I; I830-tal I; I840-tal I; I850-tal 3; I860-tal 0; I870tal I; I880-tal 8; I890-tal I4.

89 Antal träffar för sökordet "såpa": I 820-tal o; I830-tal o; I840-tal I; I850-tal 4; I860tal 2; 1870-tal 3; I880-tal 6; I890-tal 29.

90 I840 Lidköping Fant.

9I 1858 Ramnäs Häggmark.

92 186I Haparanda Wretholm.

93 I867 Skellefteå Lindström.

94 I890 Slite Holmén.

95 Ibid.

96 Ibid.

97 Lagerspetz, Olli, Smuts: En bok om världen, vårt hem, Höör: Symposion, 2007, 57; Johannisson, Karin, Kroppens tunna skal: Sex essäer om kropp, historia och kultur, Stockholm: Norstedts, 2013, 197; Johannisson, Karin, Tecknen: Läkaren och konsten att läsa kroppar, Stockholm: Norstedts, 2004, IoI; Waldetoft, Dan, ”När Rya-Rya badade", Tio tvättar sig, Westergren, Christina (red.), Stockholm: Norstedts, 2004, 68.

98 Johannisson, Kroppens tunna skal, 197.

99 I850 Vrigstad Backström.

Ioo 1897 Sandviken Melin.

IOI I8I6 Mariestads badhus Vestman.

I02 Lagerspetz, 253. 